\title{
Importance of $\mathrm{CO}_{2}$ Emissions in Construction Phase. Two Case Studies: New Construction and Renovated Building
}

\author{
Gonzalo Fernández-Sánchez ${ }^{1}$, Fernando Rodríguez-López ${ }^{2}$ \\ ${ }^{1}$ Department of Civil Engineering, Universidad Europea de Madrid, Madrid, Spain; ${ }^{2}$ Department of Civil Engineering Construction, \\ Universidad Politécnica de Madrid, Madrid, Spain. \\ Email: gonzalo.fernandez@uem.es
}

Received October $24^{\text {th }}, 2011$; revised November $28^{\text {th }}, 2011$; accepted December $10^{\text {th }}, 2011$

\begin{abstract}
With the new Technical Code for Construction and Energy Certification (application of the EPBD in Spain) energy consumption and carbon dioxide emissions are now taken into consideration during building's operating phase. There is no doubt that this is a step forward. However, economic cost and emissions involved in extracting materials, manufacture, transport and installing on site (embodied energy in the materials used in construction) can be considerable and even more when promotor seeks to improve the building's energy rating with the corresponding increases in insulation, improvements in cladding and so on. Two case studies are used (new construction and renovation) in order to analyze both economic cost and $\mathrm{CO}_{2}$ emissions in construction and operating stage (using LIDER and CALENER softwares) of two actual cases.
\end{abstract}

Keywords: Carbon Dioxide; Embodied Energy; Building; Energy Certification

\section{Introduction}

Construction sector and in particular the building sector is responsible for more than $40 \%$ of the energy consumed in Europe [1,2] and it is estimated that the implementation of the Technical Code for Construction will mean an energy saving of $30 \%-40 \%$ and a reduction in $\mathrm{CO}_{2}$ emissions of $40 \%-55 \%$ [3] in the operating phase of the buildings. However, the EPBD (Energy Performance Building Directive) does not include the indicator of Embodied Energy (EE) in the construction materials.

As other authors have observed $[2,4]$ the strategies at EU and national level are concentrating on increasing the energy efficiency of buildings, notably reducing energy needs during the operating phase without this necessarily means a reduction of energy consumption in the other stages of the building's life cycle (construction, maintenance or demolition). This fact is logical when one considers that the energy cost of buildings in the operating phase is estimated to be approximately $80 \%$ [5]. However, given that political strategies are attempting to reduce the energy consumed in the operating phase by a huge percentage, the embodied energy (EE) in the construction phase is acquiring an ever greater relative importance [5-7] and may mean between $10 \%$ and $60 \%$ of total energy used throughout the life of the building $[2,8]$.

After Royal Decree 47/2007, of 19 January, which has been mandatory in Spain since November 2007 and which fixes the bases for classifying and certifying the energy efficiency of newly constructed buildings, as well as the provisions of directive 2002/91/EC on the need for energy certification of existing buildings, which will entail a series of measures for improving the energy efficiency of every building, there is some doubt about whether improvements in thermal insulation and glazing and the introduction of new technologies aimed to reducing energy consumption in the operating phase do not considerably increase the energy consumed in the construction phase (EE).

It is clear that a reduction in energy consumption of buildings during their use is very important. However, this should not blind us to study the energy consumption in an holistic approach, what is called Life Cycle Energy Assessment (LCEA), and thus increasing the energy saving and efficiency during operation, while taking care not to increase the EE in construction phase as a result of the increased insulation materials and glazing or with the introduction of more sophisticated technological systems.

\section{Objectives and Scope}

After this short introduction, it arises the concern to study how buildings will react when they are subjected to energy classification, and how energy savings increase in the operation stage while at the same time it is analysed 
the increase of embodied energy in construction phase. RD 47/2007 gives a classification on a scale of seven letters: from class A (most efficient) to class G (least efficient) using a calculation program called CALENER, which provides theoretical ratios of energy consumption and $\mathrm{CO}_{2}$ emissions for the building during the operation phase. Buildings constructed prior to 2006, it is assumed that $40 \%$ would be in class $\mathrm{D}$, whereas for buildings constructed from 2007, it is estimated that $35 \%$ will be C and $55 \%$ will be $\mathrm{D}$ [9].

Following this idea, two actual projects have been chosen involving two buildings as case studies. The first is a newly constructed building and the second, anticipating the future Royal Decree, is a renovated building.

In both cases, the buildings were planned to be classified as D (although the classification was not yet mandatory) and the promoter insisted it should be attempted to raise its energy classification to $\mathrm{C}$. For this, an analysis of emissions was done both in construction phase and in operational phase (according to the CALENER program) comparing the project as it was originally conceived and the project finally completed to obtain the certification required by the promoter. A very brief analysis was also done of the economic cost involved in the improvement of the project and the economic saving for future users from the fact that the building is more energy efficient.

It should be pointed out that the total emissions in construction phase have not been quantified. Only the emissions of those materials that have been changed or modified during the project have been quantified.

\section{First Case Study: New Construction}

\subsection{Situation}

This concerns a development in the province of Valencia of detached houses consisting of two floors (ground floor plus one) as well as a cellar. The following characteristic data should be emphasized:

- Useful surface area of cellar: $29.88 \mathrm{~m}^{2}$

- Useful surface area of ground floor: $58.65 \mathrm{~m}^{2}$

- Useful surface area of first floor: $57.14 \mathrm{~m}^{2}$

- 3 bedrooms, 2 bathrooms, kitchen, hall and toilet

They are built using the usual materials found in this area of Spain (walls of brickwork, reinforced concrete structure and glass wool insulation) and the fuel used for heating and hot water is natural gas by means of individual combination boilers in each house.

In order to obtain an improved energy classification (from D to C) and meet the limitation of energy demand, the thickness of the insulation was increased and its thermal conductivity improved in accordance with the requirements of the original project. The following Table $\mathbf{1}$ shows the modified elements of the initial project.
Table 1. Original and improved project-new construction building.

\begin{tabular}{|c|c|c|c|}
\hline & & Original Project & Improved Project \\
\hline Wall against & Mineral & $\mathrm{e}(\mathrm{cm})=5$ & $\mathrm{e}(\mathrm{cm})=5$ \\
\hline Ground & Wool & $\lambda=0.05 \mathrm{~W} / \mathrm{mK}$ & $\lambda=0.029 \mathrm{~W} / \mathrm{mK}$ \\
\hline Wall C1 & $\begin{array}{l}\text { Mineral } \\
\text { Wool }\end{array}$ & $\begin{array}{l}\mathrm{e}(\mathrm{cm})=7 ; \\
\lambda=0.05 \mathrm{~W} / \mathrm{mK}\end{array}$ & $\begin{array}{l}\mathrm{e}(\mathrm{cm})=7 ; \\
\lambda=0.029 \mathrm{~W} / \mathrm{mK}\end{array}$ \\
\hline Wall C3 & $\begin{array}{l}\text { Mineral } \\
\text { Wool }\end{array}$ & $\begin{array}{l}\text { e }(\mathrm{cm})=5 ; \\
\lambda=0.05 \mathrm{~W} / \mathrm{mK}\end{array}$ & $\begin{array}{l}\text { e }(\mathrm{cm})=5 ; \\
\lambda=0.029 \mathrm{~W} / \mathrm{mK}\end{array}$ \\
\hline Roof & EPS & $\begin{array}{l}\mathrm{e}(\mathrm{cm})=5 ; \\
\lambda=0.029 \mathrm{~W} / \mathrm{mK}\end{array}$ & $\begin{array}{l}\mathrm{e}(\mathrm{cm})=10 ; \\
\lambda=0.029 \mathrm{~W} / \mathrm{mK}\end{array}$ \\
\hline Floor Slab & EPS & $\begin{array}{l}\mathrm{e}(\mathrm{cm})=0,1 ; \\
\lambda=0.037 \mathrm{~W} / \mathrm{mK}\end{array}$ & $\begin{array}{l}\mathrm{e}(\mathrm{cm})=6.1 ; \\
\lambda=0.037 \mathrm{~W} / \mathrm{mK}\end{array}$ \\
\hline Terrace & EPS & $\begin{array}{l}\mathrm{e}(\mathrm{cm})=5 ; \\
\lambda=0.037 \mathrm{~W} / \mathrm{mK}\end{array}$ & $\begin{array}{l}\mathrm{e}(\mathrm{cm})=5 ; \\
\lambda=0.029 \mathrm{~W} / \mathrm{mK}\end{array}$ \\
\hline Insulated Floor & EPS & $\begin{array}{l}\mathrm{e}(\mathrm{cm})=1 ; \\
\lambda=0.037 \mathrm{~W} / \mathrm{mK}\end{array}$ & $\begin{array}{l}\text { e }(\mathrm{cm})=8 ; \\
\lambda=0.037 \mathrm{~W} / \mathrm{mK}\end{array}$ \\
\hline Windows & $\begin{array}{l}\text { Glass } \\
4-12-4\end{array}$ & $\begin{array}{l}\mathrm{U}=2.9 \mathrm{~W} / \mathrm{m}^{2} \mathrm{~K} \\
\mathrm{Fs}=0.75\end{array}$ & $\begin{array}{l}\mathrm{U}=1.3 \mathrm{~W} / \mathrm{m}^{2} \mathrm{~K} \\
\mathrm{Fs}=0.64\end{array}$ \\
\hline Windows & $\begin{array}{l}\text { Glass } \\
\text { 3-3-12-3-3 }\end{array}$ & $\begin{array}{l}\mathrm{U}=2.8 \mathrm{~W} / \mathrm{m}^{2} \mathrm{~K} \\
\mathrm{Fs}=0.71\end{array}$ & $\begin{array}{l}\mathrm{U}=1.2 \mathrm{~W} / \mathrm{m}^{2} \mathrm{~K} \\
\mathrm{Fs}=0.62\end{array}$ \\
\hline
\end{tabular}

\subsection{Analysis}

As a result of the improvements introduced in the insulation and glazing, the cost of these has been evaluated, as well as the economic saving achieved during the operation (Tables 2 and $\mathbf{3}$ ).

So it can be seen that economic cost of applying the thermal improvements to the house being studied shows a difference between the cost of the elements introduced into the improved project (6210 €) and the cost of the existing units in the previous project (4623 €), which means an increase of $1587 €$.

On the other hand, the economic saving in the operating phase has been calculated considering the consumption per $\mathrm{kWh} /$ year which resulted from the application of the CALENER to each project, original and modified (Table 4).

This means an economic saving in operation for the future owner of $12 \%$ with respect to the project as it was initially conceived, this means $63.14 €$ /year less for the future user.

This means an economic saving in operation for the future owner of $12 \%$ with respect to the project as it was initially conceived, this means $63.14 €$ /year less for the future user.

Likewise, the carbon dioxide emissions incorporated into the construction materials have been calculated (Table 5), as well as the emissions in the operating phase from the data collected by the CALENER program (Table 6). 
Table 2. Cost of eliminated elements from the original project.

\begin{tabular}{lllll}
\hline & Material & Area $\left[\mathrm{m}^{2}\right]$ & Unit Price [10] & Total [€] \\
\hline $\begin{array}{l}\text { Wall against } \\
\text { Ground }\end{array}$ & Mineral Wool & 10.4 & $3.63 € / \mathrm{m}^{2}$ & 38.98 \\
Wall C1 & Mineral Wool & 226.3 & $4.49 € / \mathrm{m}^{2}$ & 1016.08 \\
Wall C3 & Mineral Wool & 45.9 & $3.63 € / \mathrm{m}^{2}$ & 166.62 \\
Roof & EPS & 67.67 & $5.15 € / \mathrm{m}^{2}$ & 348.50 \\
Floor Slab & EPS & 31.16 & - & - \\
Terrace & EPS & 9.17 & $9.35 € / \mathrm{m}^{2}$ & 85.73 \\
Windows & Glass 4-12-4 & 5.24 & $40.13 € / \mathrm{m}^{2}$ & 210.28 \\
Windows & Glass & 30.11 & $91.56 € / \mathrm{m}^{2}$ & 2756.87 \\
& $3-3-12-3-3$ & & & \\
& & & TOTAL & $4623 €$ \\
\hline
\end{tabular}

Table 3. Cost of new elements introduced into improved project.

\begin{tabular}{lllll} 
& Material & Area $\left[\mathrm{m}^{2}\right]$ & Unit Price [10] & Total $[€]$ \\
\hline $\begin{array}{l}\text { Wall against } \\
\text { Ground }\end{array}$ & Mineral Wool & 10.74 & $5.15 € / \mathrm{m}^{2}$ & $55.31 €$ \\
Wall C1 & Mineral Wool & 226.3 & $7.11 € / \mathrm{m}^{2}$ & 1608.99 \\
Wall C3 & Mineral Wool & 45.9 & $5.15 € / \mathrm{m}^{2}$ & 236.38 \\
Roof & EPS & 67.67 & $9.35 € / \mathrm{m}^{2}$ & 632.71 \\
Floor slab & EPS & 31.16 & $5.9 € / \mathrm{m}^{2}$ & 183.84 \\
Terrace & EPS & 9.17 & $5.15 € / \mathrm{m}^{2}$ & 47.22 \\
Insulated Floor & EPS & 5.6 & $7.11 € / \mathrm{m}^{2}$ & 39.82 \\
Windows & Glass 4-12-4 & 5.24 & $44.87 € / \mathrm{m}^{2}$ & 235.12 \\
Windows & Glass & 30.11 & $105.3 € / \mathrm{m}^{2}$ & 3170.58 \\
\hline & $3-3-12-3-3$ & 30.11 & & \\
& & & TOTAL & $6210 €$
\end{tabular}

Table 4. Operating costs from consumption energy (according to CALENER).

\begin{tabular}{lcccc}
\hline & \multicolumn{2}{l}{ Original project } & \multicolumn{2}{l}{ Improved project } \\
\hline & kwh/year & $€ /$ year & kwh/year & $€ /$ year \\
\hline Calefacción & 3889.389 & 162.03 & 2196.60 & 91.51 \\
Refrigeración & 3729.152 & 335.13 & 3811.31 & 342.52 \\
Total & 7618.541 & 497.16 & 6007.91 & 434.03 \\
\hline
\end{tabular}

Table 5. $\mathrm{CO}_{2}$ emissions in Original and improved project.

\begin{tabular}{|c|c|c|c|}
\hline & & $\begin{array}{l}\text { Emissions }\left[\mathrm{kg} \mathrm{CO}_{2}\right] \\
\text { Original Project }\end{array}$ & $\begin{array}{l}\text { Emissions }\left[\mathrm{kg} \mathrm{CO}_{2}\right] \\
\text { Improved Project }\end{array}$ \\
\hline $\begin{array}{l}\text { Wall against } \\
\text { Ground }\end{array}$ & Mineral Wool & $13.21 \mathrm{~kg}$ & $97.41 \mathrm{~kg}$ \\
\hline Wall C1 & Mineral Wool & $391.50 \mathrm{~kg}$ & $2871.75 \mathrm{~kg}$ \\
\hline Wall C3 & Mineral Wool & $56.46 \mathrm{~kg}$ & $416.31 \mathrm{~kg}$ \\
\hline Roof & EPS & $613.77 \mathrm{~kg}$ & $1226.86 \mathrm{~kg}$ \\
\hline Floor Slab & EPS & - & $339.02 \mathrm{~kg}$ \\
\hline Terrace & EPS & $166.25 \mathrm{~kg}$ & $83.17 \mathrm{~kg}$ \\
\hline $\begin{array}{l}\text { Insulated } \\
\text { Floor }\end{array}$ & EPS & - & $71.06 \mathrm{~kg}$ \\
\hline Windows & Glass 4-12-4 & $114.23 \mathrm{~kg}$ & $129.53 \mathrm{~kg}$ \\
\hline Windows & $\begin{array}{l}\text { Glass } \\
\text { 3-3-12-3-3 }\end{array}$ & $1012.30 \mathrm{~kg}$ & $1032.17 \mathrm{~kg}$ \\
\hline TOTAL: & & $2367.71 \mathrm{~kg}$ & $6267.28 \mathrm{~kg}$ \\
\hline
\end{tabular}

Table 6. $\mathrm{CO}_{2}$ emissions in operation.

\begin{tabular}{|c|c|c|c|c|}
\hline & \multicolumn{2}{|l|}{ Original Project } & \multicolumn{2}{|l|}{ Improved Project } \\
\hline & $\mathrm{kg} \mathrm{CO}_{2} / \mathrm{m}^{2}$ year & $\mathrm{kg} \mathrm{CO}_{2} /$ year & $\mathrm{kg} \mathrm{CO} / \mathrm{m}^{2}$ year & $\mathrm{kg} \mathrm{CO}_{2} /$ yeal \\
\hline Heating & 6.9 & 1003.743 & 4.4 & 596.427 \\
\hline Cooling & 7.4 & 1076.478 & 8 & 1163.76 \\
\hline Total & 14.3 & 2008.221 & 12.4 & 1760.187 \\
\hline
\end{tabular}

The increase in carbon dioxide emissions in the construction phase due to the improvements is $3899.57 \mathrm{~kg}$ $\mathrm{CO}_{2}(6267.28 \mathrm{~kg}-2367.71 \mathrm{~kg})$. On the other hand, it leads to an annual reduction of $15 \%$ during the operational phase, $320 \mathrm{~kg}$ of $\mathrm{CO}_{2}$ per year less.

\section{Second Case Study: Renovated Building}

\subsection{Situation}

This concerns the renovation of a building consisting of four apartments in Madrid, two of them on the first floor and two on the second floor. The ground floor has an area for a garage. The renovation consists of increasing the number of apartments to seven, three on the first floor, three on the second and a new one in the attic retaining the ground floor as a garage and modifying the composition of the façades to improve the energy classification from $\mathrm{D}$ to $\mathrm{C}$.

The surface area of each original floor is $111.62 \mathrm{~m}^{2}$ (ground, first and second floor) and the attic is an additional $54.5 \mathrm{~m}^{2}$.

The changes made to the original project for the renovation and to improve the thermal insulation are shown in the following table (Table 7). 
Table 7. Original and renovated project.

\begin{tabular}{lllll}
\hline & Original Project & & Renovation Project & \\
\hline Façade GF & solid brick & $\mathrm{e}=26.5 \mathrm{~cm}$ & solid brick $+1.5 \mathrm{~cm}$ rendering & $\mathrm{e}=28 \mathrm{~cm}$ \\
Façade AT & HD brick & $\mathrm{e}=24 \mathrm{~cm}$ & HD brick $+3 \mathrm{~cm} \mathrm{PU}+1.2 \mathrm{~cm} \mathrm{PYL}$ & $\mathrm{e}=28.2 \mathrm{~cm}$ \\
Roof & $16 \mathrm{~cm}+$ catalan terrace & $\mathrm{e}=16 \mathrm{~cm}$ & $16 \mathrm{~cm}+$ catalan terrace + asphalt sheet + EPS & $\mathrm{e}=20 \mathrm{~cm}$ \\
& & & $\mathrm{e}=1.4 \mathrm{~cm}$ \\
Windows & Metal + glass & $\mathrm{e}=0.4 \mathrm{~cm}$ & Lacquered Aluminium Windows and 2 glass $4-6-4$ & $\mathrm{Fs}=0.75$ \\
& & $\mathrm{U}=5.65 \mathrm{w} / \mathrm{m}^{2} \mathrm{~K}$ & & $\mathrm{U}=3.3 \mathrm{w} / \mathrm{m}^{2} \mathrm{~K}$ \\
\hline
\end{tabular}

\subsection{Analysis}

After the project modification for its renovation, cost of the modified elements is analyzed as well as saving that will suppose during the operation phase. The Table 8 shows the cost of the planned improvements that affect the insulation.

The total cost of the improvements introduced in the thermal insulation of the renovated building is $26,920 €$. On the other hand the economic saving in the operational phase for energy consumption calculated by means of CALENER supposses an annual reduction of 10\%, 140.08 $€ /$ year less (Table 9).

In view of this results, it might seems that the improvement is very small, but considering the indicators of consumption of $\mathrm{kWh} / \mathrm{m}^{2}$ for the house, the original project consumed $123.3 \mathrm{kWh} / \mathrm{m}^{2}$ a year and after the renovation it is $88.3 \mathrm{kWh} / \mathrm{m}^{2}$, and economically the original project had a cost for energy consumption in operation of $5.11 € / \mathrm{m}^{2}$ whereas the renovation lowers that amount to $3.66 € / \mathrm{m}^{2}$.

As was done with the first study, it is showed an analysis of the carbon dioxide emissions incorporated into the construction materials to be used for the improvement of the insulation during the construction phase (Table 10).

It can be seen that the carbon dioxide saving due to the renovation is $4134.21 \mathrm{~kg} \mathrm{CO}_{2}$ a year, it leads to an annual reduction of $34 \%$ with respect to the original project (Table 11).

\section{Conclusions}

In view of the results obtained in both case studies and from what is said in the introduction, we may conclude the following:

- The economic cost of the investments to improve the energy classification of a building can mean an important saving over the life cycle of the building (LCC) even though there may be a long period of amortization (20 - 25 years in the case of new construction).

- The increase in carbon dioxide emissions in the construction phase due to the increase in insulation and improvements in the glazing of the two buildings studied supposes high but amortizable values in the operating phase over a period of 12 years (case one
Table 8. Cost of new elements introduced into the improved project.

\begin{tabular}{|c|c|c|c|c|}
\hline & \multicolumn{4}{|c|}{ Renovation project } \\
\hline & Material & Area $\left[\mathrm{m}^{2}\right]$ & Unit Price & Total Cost [€] \\
\hline Façade GF & Rendering $1.5 \mathrm{~cm}$ & 137 & $17.46 € / \mathrm{m}^{2}$ & 2392.0 \\
\hline \multirow{2}{*}{ Façade AT } & Polyurethano $3 \mathrm{~cm}$ & 307 & $7.23 € / \mathrm{m}^{2}$ & 2219.6 \\
\hline & PYL $1.2 \mathrm{~cm}$ & 307 & $25.4 € / \mathrm{m}^{2}$ & 7797.8 \\
\hline \multirow{3}{*}{ Roof } & Asphalt sheet & 151 & $19.97 € / \mathrm{m}^{2}$ & 3015.5 \\
\hline & EPS $4 \mathrm{~cm}$ & 151 & $6.81 € / \mathrm{m}^{2}$ & 1028.3 \\
\hline & $\begin{array}{l}\text { Aluminum windows } \\
1.15 \times 2.25\end{array}$ & $8 \mathrm{u}$ & $340.8 € /$ ud & 2726.4 \\
\hline \multirow{4}{*}{ Windows } & $\begin{array}{l}\text { Aluminum windows } \\
1.50 \times 2.25\end{array}$ & $11 \mathrm{u}$ & $408.47 € / \mathrm{ud}$ & 4493.2 \\
\hline & $\begin{array}{l}\text { Aluminum windows } \\
1.50 \times 1.25\end{array}$ & $3 \mathrm{u}$ & $228.34 € /$ ud & 685.0 \\
\hline & Glass 4-6-4 & 67 & $38.25 € / \mathrm{m}^{2}$ & 2562.7 \\
\hline & & & TOTAL & $26,920 €$ \\
\hline
\end{tabular}

Table 9. Operating costs for energy consumption.

\begin{tabular}{ccccc}
\hline & \multicolumn{2}{c}{ Existing Project } & \multicolumn{2}{c}{ Renovated Project } \\
\hline & $\mathrm{kWh} /$ year & $€ /$ year & $\mathrm{kWh} /$ year & $€ /$ year \\
\multirow{2}{*}{ Total } & 33648.57 & 1396.41 & 30273.24 & 1256.33 \\
\hline
\end{tabular}

Table 10. $\mathrm{CO}_{2}$ emissions incorporated into the insulated materials.

\begin{tabular}{lll}
\hline & Materials & Total Emissions $\left[\mathrm{kg} \mathrm{CO}_{2}\right]$ \\
\hline Façade GF & Rendering $1.5 \mathrm{~cm}$ & $902.83 \mathrm{~kg}$ \\
Façade AT & Polyurethano $3 \mathrm{~cm}$ & $3997.14 \mathrm{~kg}$ \\
& PYL $1.2 \mathrm{~cm}$ & $5209.79 \mathrm{~kg}$ \\
Roof & Asphalt sheet & $6701.38 \mathrm{~kg}$ \\
& EPS $4 \mathrm{~cm}$ & $1289.54 \mathrm{~kg}$ \\
& Aluminum windows & $11067.52 \mathrm{~kg}$ \\
Windows & $1.15 \times 2.25$ & \\
& Aluminum windows & $1.50 \times 2.25$ \\
& Aluminum windows & \\
& $1.50 \times 1.25$ & $2593.95 \mathrm{~kg}$ \\
Glass 4-6-4 & & $1460.6 \mathrm{~kg}$ \\
& Total: & $52245.05 \mathrm{~kg}$ \\
\hline
\end{tabular}


Table 11. $\mathrm{CO}_{2}$ emissions in operation.

\begin{tabular}{ccccc}
\hline & \multicolumn{2}{c}{ Existing Project } & \multicolumn{2}{c}{ Renovated Project } \\
\hline & $\mathrm{kg} \mathrm{CO}_{2} / \mathrm{m}^{2}$ & $\mathrm{~kg} \mathrm{CO}_{2}$ & $\mathrm{~kg} \mathrm{CO}_{2} / \mathrm{m}^{2}$ & $\mathrm{~kg} \mathrm{CO}_{2}$ \\
Total & 45.3 & 12362.37 & 24 & 8228.16 \\
\hline
\end{tabular}

and two). These results demonstrate the discrepancy between economic and environmental amortization (25 years against 12 years in the new building).

- It seems clear that, as we said at the beginning of the paper, the introduction into European norms of a limit to energy demand, together with the certification of buildings in the operating phase, are first steps and there is no doubt that this is the stage where most energy is consumed. However, the figures obtained in this study as well as the resulting values given in the literature consulted, make it clear that when the values of energy consumption are reduced during the operational phase, the construction phase starts to gain more importance.

- In order to reduce overall energy consumption, as well as carbon dioxide emissions, yet further, we believe it is necessary to introduce tools into the decision making that take into consideration the life cycle of the building, with special emphasis on the embodied energy of the materials. So, in the case of study one, the same energy certification could be obtained by reducing emissions far more in the construction phase. For example, expanded polystyrene (EPS) was used to improve insulation and this has an emission factor up to 10 times higher than that of glass wool.

- Finally, it must be stressed that any improvement in the energy classification of a building (such as the ones that have been studied here) means an increase in carbon dioxide emissions in the construction phase due to the increase of construction materials such as insulation and glazing, which means not only paying attention to improving energy classification but also making correct choices about the materials to be used.

\section{Acknowledgements}

The authors appreciate the collaboration of the company CPV (Control, Prevención y Verificación) for the help provided in the study of the projects described in this article, as well as for being available to help when preparing this study.

\section{REFERENCES}

[1] X. G. Casals, “Analysis of Building Energy Regulation and Certification in Europe: Their Role, Limitations and Differences," Energy and Buildings, Vol. 138, No. 5, 2006, pp. 381-392. doi:10.1016/j.enbuild.2005.05.004

[2] A. Z.-Z. Szalay, "What Is Missing from the Concept of the New European Building Directive?" Building and Environment, Vol. 42, No. 4, 2007, pp. 1761-1769. doi:10.1016/j.buildenv.2005.12.003

[3] I. Oteiza and J. A. Tenorio, "La Innovación en las Técnicas, los Sistemas y los Materiales de Construcción,” Jornada 7: Evaluación de la sostenibilidad en la edificación, XVII Edición Curso de Estudios Mayores de la Construcción (CEMCO), Madrid, 8 Febrero al 22 de Junio de 2007.

[4] N. Huberman and D. Pearlmutter, "A Life-Cycle Energy Analysis of Building Materials in the Negev Desert," Energy and Buildings, Vol. 40, No. 5, 2008, pp. 837-848. doi:10.1016/j.enbuild.2007.06.002

[5] RAIA, "Towards a National Framework for Energy Efficiency-Issues and Challenges,” The Royal Australian Institute of Architects (RAIA), Tusculum, 2004.

[6] T. Mumma, "Reducing the Embodied Energy of Buildings,” Home Energy Magazine, Vol. 12, No. 1, 1995, pp. 9-12.

[7] R. Cole and P. C. Kernan, "Life-Cycle Energy Use in Office Buildings,” Building and Environment, Vol. 31, No. 4, 1996, pp. 307-317. doi:10.1016/0360-1323(96)00017-0

[8] C. Thormark, "A Low Energy Building in a Life CycleIts Embodied Energy, Energy Need for Operation and Recycling Potential,” Building and Environment, Vol. 37, No. 4, 2002, pp. 429-435. doi:10.1016/S0360-1323(01)00033-6

[9] F. M. Samper and F. R. R. de Gopegui, “Oportunidades para las Ingenierías ante el RD 47/2007 de Eficiencia Energética,” V Congreso Nacional de Ingeniería Civil: Desarrollo y Sostenibilidad en el Marco de la Ingeniería, Sevilla, 2007.

[10] Institut de Tecnología de la Construcció de Catalunya, "Base de datos Banco BEDEC PR/PCT," 2009. www.itec.es 